\title{
Organizations and People
}

\section{Ablereviations}

AAVSO - American Association of Variable Star Observers, based in Cambridge, Massachusetts

IGY — International Geophysical Year, which ran from July 1957 to

December 1958

NAS — National Academy of Sciences, established in 1863 and headquartered in Washington, D.C.

NASA — National Aeronautics and Space Administration, formed in 1958

NSF — National Science Foundation, established in 1950 and located in

Washington, D.C.

SAO — Smithsonian Astrophysical Observatory, located in Cambridge, Massachusetts

\section{Cast of Characters}

In Cambridge, Massachusetts

James Baker - Astronomer and optical engineer who developed, along with Joseph Nunn, the basic design of the Baker-Nunn camera

Leon Campbell, Jr. — Moonwatch's director from 1956 to 1961

William Hirst — Moonwatch director from 1964 to 1968

J. Allen Hynek - Astronomer and director of the SAO's satellite tracking program during the IGY

Walter Munn — Field representative for the SAO

Armand Spitz — Early Moonwatch organizer, science popularizer, and planetarium builder

Richard Vanderburgh — Moonwatch director from 1961 to 1964

Albert Werner - Moonwatch director from 1968 until the program's end in 1975 


\section{xii Organizations and People}

Fred Whipple - Astronomer and director of Smithsonian Astrophysical Observatory from 1955 to 1973

In Washington, D.C.

Lloyd Berkner — Vice-president of the entire International Geophysical Year

Leonard Carmichael — Secretary of the Smithsonian Institution Joseph Kaplan — UCLA physicist and chairman of the United States National Committee for the IGY (referred to, in the book, simply as the "National Committee")

Hugh Odishaw - Executive director of the U.S. IGY program who operated out of the National Academy of Sciences

S. Paul Kramer - Odishaw's assistant at the National Academy of Sciences

Richard Porter - Electrical engineer for General Electric and chairman of the Technical Panel for the Earth Satellite Program (in the book, the "Satellite Panel”)

Homer Newell — Leading scientist for the navy's Vanguard satellite program

\section{Prominent MoONwatchers}

Bro. Wendell Adams, New Orleans, Louisiana

Nunz Addabbo, Terre Haute, Indiana

Jack Bartholdi, Albuquerque, New Mexico

Jack Borde, Walnut Creek, California

Don Charles, Walnut Creek, California

Philip del Vecchio, Paterson, New Jersey

Sally Dieke, Baltimore, Maryland

Russell Eberst, United Kingdom

Richard Emmons, North Canton, Ohio

Paul Engle, Edinburg, Texas

Rodney Faxon, Chicago, Illinois

Edward Halbach, Milwaukee, Wisconsin

Vioalle Hefferan, Albuquerque, New Mexico

Walter Scott Houston, Manhattan, Kansas 
Neale Howard, Milbrook, New York

Arthur Leonard, Sacramento, California

Stephen Maran, New York, New York

Ed Martz, Alamogordo, New Mexico

Massasi Miyadi, Tokyo, Japan

Ted Molczan, Hamilton, Ontario

Miss Charlie Noble, Fort Worth, Texas

Jay Pasachoff, New York City

Tom Petrie, Cleveland, Ohio

Dave Saltus, Arlington, Virginia

Jane Shelby, New York City

Victor Slabinski, Cleveland, Ohio

Geoffrey Taylor, Adelaide, Australia

Tom Van Flandern, Cleveland, Ohio

Joel Weisberg, Albuquerque, New Mexico

Jim Westphal, Tulsa, Oklahoma

Donald Zahner, St. Louis, Missouri 



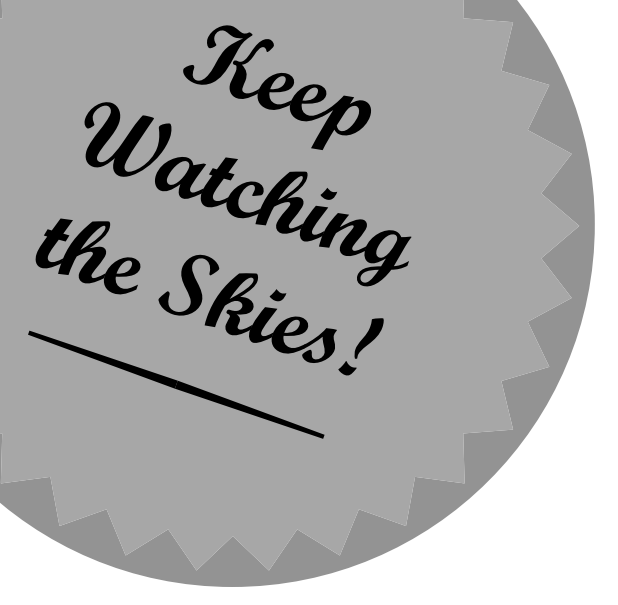


